Polynuclear Complexes

DOI: $10.1002 /$ anie. 200500716

\section{Carbon Dioxide Activation Assisted by a Bis(chlorodimethylsilyl)cyclopentadienyl Titanium Compound ${ }^{* *}$}

\section{David Santamaría, Jesús Cano, Pascual Royo,* Marta E. G. Mosquera, Tomás Cuenca, * Luis M. Frutos, and Obis Castaño}

A great deal of interest has focused on the role of metal ions as the active centers in the fixation of $\mathrm{CO}_{2}$ and its transformation. ${ }^{[1]}$ Activation of $\mathrm{CO}_{2}$ by hydroxo and oxo metal complexes to afford metal hydrogencarbonato and carbonato species, respectively, is related to the function of the carbonic anhydrase metalloenzyme, ${ }^{[2]}$ which catalyzes the physiologically important hydration of $\mathrm{CO}_{2}$ to hydrogencarbonate [Eq. (1)].

$$
[\mathrm{M}]-\mathrm{OH} \text { or }[\mathrm{M}]-\mathrm{O}-[\mathrm{M}] \stackrel{\mathrm{CO}_{2}}{\longrightarrow}[\mathrm{M}]-\mathrm{CO}_{3} \mathrm{H} \text { or }[\mathrm{M}]-\mathrm{CO}_{3}-[\mathrm{M}]
$$

This type of reaction is common for the late-transition metals $^{[3]}$ and is known for main-group organometallic species. ${ }^{[4]}$ Nevertheless, the carbonato derivatives reported for complexes of Group 4-6 metals are synthesized by alternative methods ${ }^{[5]}$ based on reactions of metal precursor compounds with carbonate salts $\mathrm{X}_{2} \mathrm{CO}_{3}\left(\mathrm{X}=\mathrm{K}, \mathrm{Bu}_{4} \mathrm{~N}\right)$ and $\mathrm{NH}_{4} \mathrm{HCO}_{3}$ or by methods that involve the disproportionation of $\mathrm{CO}_{2}$.

Herein, we describe the use of the bis(chlorodimethylsilyl)cyclopentadienyl titanium(IV) compound $\mathbf{1},{ }^{[6]}$ which was reported previously for the in situ activation of $\mathrm{CO}_{2}$. The carbonato titanium(III) derivative $\mathbf{3}$ was serendipitously obtained when a dilute solution of $\mathbf{1}$ in wet toluene was exposed to air for several days (Scheme 1). This reaction proceeded in better yield ( $43 \%$ after purification) when a solution of $\mathbf{1}$ in toluene was treated with a saturated aqueous solution of $\mathrm{CO}_{2}$ to give $\mathbf{3}$, which was isolated as an analytically pure and highly air-stable diamagnetic orange crystalline solid. However, hydrolysis of $\mathbf{1}$ carried out in the presence of $\mathrm{NEt}_{3}$ resulted in no reaction with $\mathrm{CO}_{2}$ and the $\mu$-oxo

[*] D. Santamaría, Dr. J. Cano, Prof. P. Royo, Dr. M. E. G. Mosquera, Prof. T. Cuenca

Departamento de Química Inorgánica

Universidad de Alcalá

Campus Universitario, 28871 Alcalá de Henares (Spain)

Fax: (+34) 918-854-683

E-mail: pascual.royo@uah.es tomas.cuenca@uah.es

Dr. L. M. Frutos, Prof. O. Castaño

Departamento de Química-Física

Universidad de Alcalá

Campus Universitario, 28871 Alcalá de Henares (Spain)

[**] Financial Support by the Spanish MEC (project MAT2004-02614) and MCyT (project BQU2003-07281) is acknowledged.

D. Supporting information for this article is available on the WWW under http://www.angewandte.org or from the author.<smiles>C[Si](C)(Cl)c1ccc([Si](C)(Cl)Cl)cc1</smiles><smiles>C[Si](C)(Cl)c1ccc([Si](C)(O)Cl)cc1</smiles><smiles>[M][Si](C)(Cl)c1ccc([Si](O)([Si])Cl)cc1</smiles>

B
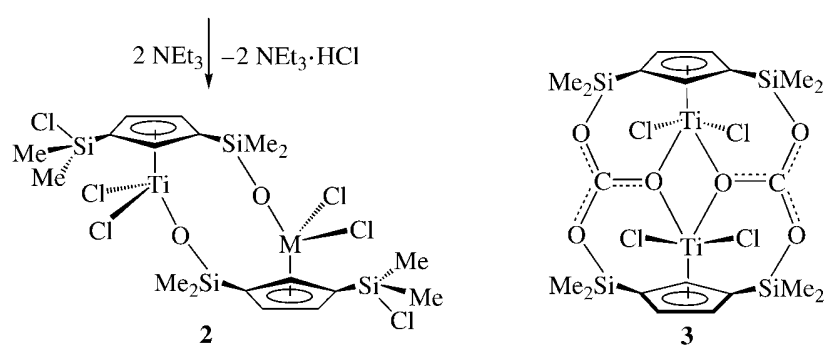

Scheme 1. Possible reaction pathways for the synthesis of $\mathbf{2}$ and $\mathbf{3}$.

titanium(IV) derivative 2 and $\mathrm{NEt}_{3} \cdot \mathrm{HCl}$ being obtained (Scheme 1). The reaction of $\mathbf{1}$ with $\mathrm{K}_{2} \mathrm{CO}_{3}$ in THF or toluene afforded a mixture of unidentified compounds that did not contain 3 .

Hydrolysis of the Group 4 metal/chloro complexes usually proceeds with initial transformation of the metal-chlorine bonds so that intermediate complexes are formed which contain rather uncommon, discrete terminal Group 4 metalhydroxo bonds. ${ }^{[7]}$ These species subsequently condense to give polynuclear compounds stabilized by $\mu$-oxo bridges. ${ }^{[8]} \mathrm{We}$ propose that the carbonato complex 3 results from the in situ formation of intermediate $\mathrm{Si}-\mathrm{OH} / \mathrm{Ti}-\mathrm{OH}$ terminal bonds (see $\mathbf{A}$ and $\mathbf{B}$ in Scheme 1) and a further insertion reaction of $\mathrm{CO}_{2}$ with simultaneous reduction to the highly stable titanium(III) compound $\mathbf{3}$. This mechanism of formation is consistent with the high stability of $\mathbf{3}$, which remains unaltered when left for weeks in air; with the formation of the $\mu$-oxo complex $\mathbf{2}$ in the presence of a deprotonating agent; and also with the observed stability of $\mathbf{2}$, as it did not react with $\mathrm{CO}_{2}$ to give $\mathbf{3}$ after several days at temperatures higher than $120^{\circ} \mathrm{C}$.

The ${ }^{1} \mathrm{H}$ NMR spectrum $\left(\mathrm{CDCl}_{3}, 25^{\circ} \mathrm{C}\right)$ of complex 3 shows behavior expected for a $C_{2 h}$-symmetric molecule with an $\mathrm{A}_{2} \mathrm{~B}$ spin system for the cyclopentadiene $(\mathrm{Cp})$ protons and with two resonances of the two nonequivalent methyl groups of the four equivalent $\left\{\mathrm{SiMe}_{2}\right\}$ fragments (see Experimental Section). The resonances of the carbon atoms of the two equivalent bridging carbonato ligands are observed in the ${ }^{13} \mathrm{C}$ NMR spectrum as one signal at $\delta=183.7 \mathrm{ppm}$. The IR spectrum shows the characteristic $v(\mathrm{C}-\mathrm{O})$ absorption of the carbonato ligand at $1375 \mathrm{~cm}^{-1}$. The ${ }^{1} \mathrm{H}$ and ${ }^{13} \mathrm{C}$ NMR spectra $\left(\mathrm{CDCl}_{3}, 25^{\circ} \mathrm{C}\right)$ of complex 2 show behavior expected for a disymmetric molecule with two resonances for the diastereotopic methyl groups of two equivalent $\left\{\mathrm{SiMe}_{2} \mathrm{O}\right\}$ fragments rather than the singlet observed for the related symmetrical complex $\left[\left\{\mathrm{TiCl}_{2}\left[\mu-\left(\mathrm{OSiMe}_{2}-\eta^{5}-\mathrm{C}_{5} \mathrm{H}_{4}\right)\right]\right\}_{2}\right]^{[9]}$ reported previ- 
ously. The resonances for the $\mathrm{SiMe}_{2} \mathrm{Cl}$ protons of $\mathbf{2}$ appear as two singlets with chemical shifts analogous to those observed for $\mathbf{1}$ and for $\left[\mathrm{TiCl}_{3}\left(\eta^{5}-\mathrm{C}_{5} \mathrm{H}_{4} \mathrm{SiMe}_{2} \mathrm{Cl}\right)\right] .{ }^{[9]}$

The molecular structure of $\mathbf{3}^{[10]}$ was determined by X-ray diffraction (Figure 1), which indicates a square-base pyramid coordination for the titanium center. The $\left\{\mathrm{Ti}_{2} \mathrm{O}_{2}\right\}$ core is planar, with the two carbonato ligands and the four $\mathrm{Si}$ atoms also located in a second plane (maximum deviation= $0.0447 \AA$ ) with the dihedral angle between the planes at $128^{\circ}$. The Ti-Ti distance (3.2901(9) $\AA$ ) is longer than that expected for a conventional Ti-Ti bond (ca. 2.68-2.85 $\AA$ ). ${ }^{[1]}$
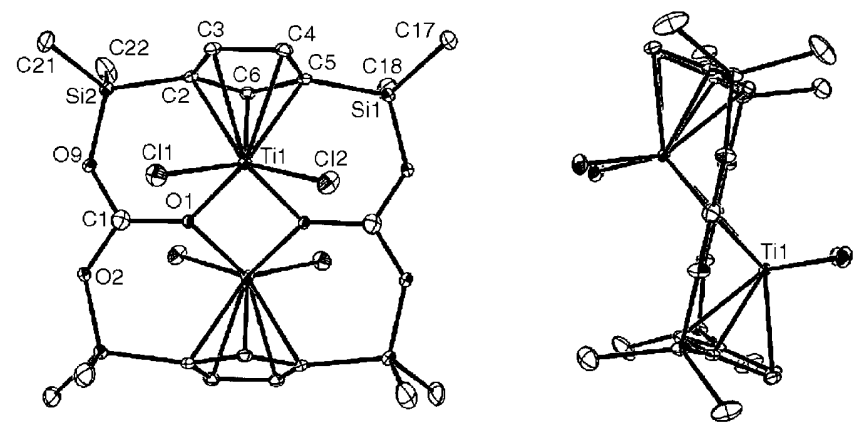

Figure 1. ORTEP view of $\mathbf{3}$, with $30 \%$ probability ellipsoids. Selected bond lengths $[\AA]$ and angles $\left[{ }^{\circ}\right]$. Ti-Ti 3.2901 (9), C1-O2 1.353(3), C1-O9 $1.357(3), \mathrm{Cl}-\mathrm{O} 1 \mathrm{1} 1.407(3)$, Ti1-O1 2.0495(14); O2-C1-O9 116.9(2), O2C1-O1 121.6(2), O9-C1-O1 121.4(2), Cl2-Ti1-Cl1 89.21(3).

To clarify the nature of the $\operatorname{Ti}\left(\mathrm{d}^{1}\right)-\operatorname{Ti}\left(\mathrm{d}^{1}\right)$ electron coupling and, consequently, the diamagnetism of the molecule, we carried out a theoretical investigation of the electronic properties of 3. Single-determinant wave functions (Hartree-Fock), as well as DFT methods, ${ }^{[12]}$ failed to explain the stability of the singlet state of this molecule. ${ }^{[13]}$ This fact reflects the importance of the correlation energy in the study of the $d^{1}-d^{1}$ electron coupling. Only by including the correlation energy ${ }^{[14]}$ through the second-order-perturbation method (MP2) $)^{[15]}$ is it possible to explain the high stability of the singlet species, which is $57.6 \mathrm{kcal} \mathrm{mol}^{-1}$ more stable than the triplet state $\left(49.2 \mathrm{kcal} \mathrm{mol}^{-1}\right.$, as obtained from the X-ray crystal structure), and hence its diamagnetic character. The $\mathrm{d}^{1}-\mathrm{d}^{1}$ electron coupling basically arose from the in-phase interacting $\mathrm{d}_{z^{2}}$-like orbitals located in each Ti atom (Figure 2). This in-phase orbital interaction collects almost all of the electronic density between the two Ti atoms, ${ }^{[16]}$ as it is the principal interaction responsible for the spin pairing. Also,
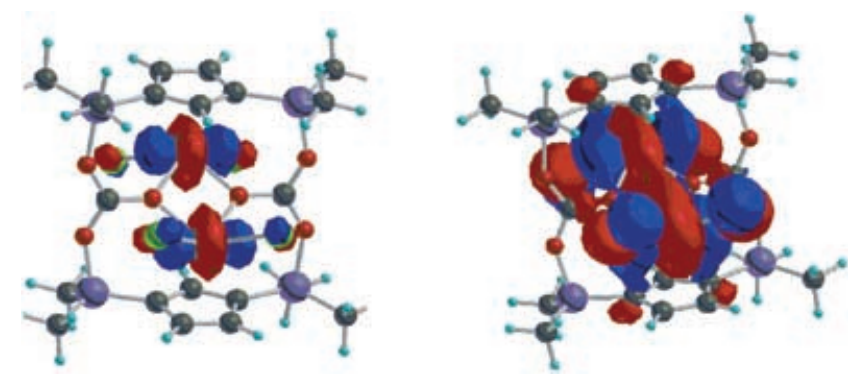

Figure 2. Depiction of the highest-occupied molecular orbitals showing the Ti-Ti in-phase orbital interaction at two different wave-function amplitudes (0.04 and 0.02 (left and right, respectively)). Minor contributions from the two annular oxygen atoms are present. minor contributions from the two bridging oxygen atoms increase the strength of the interaction (Figure 2).

The Ti-Ti in-phase orbital interaction is strong enough to provide a high stability to the singlet species, as this state is only populated at room temperature. An $\mathrm{S}_{0} / \mathrm{T}_{1}$ intersystem crossing should not be an efficient path to populate the triplet state, as a result of low spin-orbit coupling ${ }^{[17]}$ as well as the high $\mathrm{S}_{0}-\mathrm{T}_{1}$ energy gap.

In summary, we have demonstrated that a bis(chlorodimethylsilyl)cyclopentadienyl titanium(Iv) derivative can fix $\mathrm{CO}_{2}$ and transform it into a carbonato ligand with simultaneous reduction to give an air-stable diamagnetic titanium(III) compound. A theoretical investigation of the electronic properties of the molecule demonstrates the high stability of the singlet versus the triplet state and justifies the diamagnetism exhibited by the carbonato complex $\mathbf{3}$.

\section{Experimental Section}

2: Distilled and degassed water $(27 \mu \mathrm{L}, 1.49 \mathrm{mmol})$ and $\mathrm{NEt}_{3}$ $(0.42 \mathrm{~mL}, 2.96 \mathrm{mmol})$ were added to a solution of $\mathbf{1}(0.6 \mathrm{~g}$, $1.48 \mathrm{mmol})$ in toluene $(50 \mathrm{~mL})$. The cloudy reaction mixture was stirred over $24 \mathrm{~h}$ at room temperature and then filtered to give a paleorange solution. The solvent was removed under vacuum and the residue was extracted with hexane. The resulting solution was concentrated to $20 \mathrm{~mL}$ and cooled to $-35^{\circ} \mathrm{C}$ to give a light-orange solid which was isolated by filtration and identified as $2(0.58 \mathrm{~g}$, $0.827 \mathrm{mmol}) 56 \%$ yield. Elemental analysis (\%) calcd for $\mathrm{C}_{18} \mathrm{H}_{30} \mathrm{O}_{2} \mathrm{Si}_{4} \mathrm{Ti}_{2} \mathrm{Cl}_{6}$ : C 30.92, H 4.32; found: $\mathrm{C} 30.75, \mathrm{H}$ 4.48; ${ }^{1} \mathrm{H}$ NMR $\left(300 \mathrm{MHz}, \mathrm{CDCl}_{3}\right): \delta=0.55,0.60,0.78,0.83(4 \mathrm{~s}, 4 \times 6 \mathrm{H}$, $\left.\mathrm{SiMe}_{2}\right), 7.06,7.19,7.35 \mathrm{ppm}\left(3 \mathrm{~m}, 3 \times 2 \mathrm{H}, \mathrm{C}_{5} \mathrm{H}_{3}\right) ;{ }^{13} \mathrm{C} \mathrm{NMR}(300 \mathrm{MHz}$, $\left.\mathrm{CDCl}_{3}\right): \delta=0.2,0.6,2.5,2.9\left(4 \times \mathrm{SiMe}_{2}\right), 127.4,130.7,134.0\left(\mathrm{C}_{5} \mathrm{H}_{3}\right)$, 133.7, $135.4 \mathrm{ppm}\left(\mathrm{C}_{\mathrm{ipso}}, \mathrm{C}_{5} \mathrm{H}_{3}\right)$.

3: An excess of distilled and degassed water $(67 \mu \mathrm{L}, 3.70 \mathrm{mmol})$ was added to a pale-yellow solution of $\mathbf{1}(0.3 \mathrm{~g}, 0.74 \mathrm{mmol})$ in toluene $(200 \mathrm{~mL})$ saturated with $\mathrm{CO}_{2}$. Formation of the same white solid suspension described above was observed. The reaction mixture was stirred over $42 \mathrm{~h}$ at room temperature. After that time, the reaction mixture changed to pale orange. The solvent was removed to give an orange solid that was extracted with a mixture of toluene/pentane and isolated as an orange crystalline solid identified as $3(0.27 \mathrm{~g}$, $0.086 \mathrm{mmol}) 43 \%$ yield. Single crystals of $\mathbf{3}$ suitable for X-ray diffraction studies were grown from a solution of $\mathrm{CHCl}_{3}$. Elemental analysis (\%) calcd for $\mathrm{C}_{22} \mathrm{H}_{32} \mathrm{O}_{6} \mathrm{Si}_{4} \mathrm{Ti}_{2} \mathrm{Cl}_{10}$ : C 27.67, H 3.38; found: $\mathrm{C}$ 27.87, H 3.44; ${ }^{1} \mathrm{H}$ NMR ( $\left.300 \mathrm{MHz}, \mathrm{CDCl}_{3}\right): \delta=0.51,0.60(2 \mathrm{~s}, 2 \times 12 \mathrm{H}$, $\left.\mathrm{SiMe}_{2}\right), 6.88\left(\mathrm{~m}, 2 \mathrm{H}, \mathrm{C}_{5} \mathrm{H}_{3}\right), 7.88 \mathrm{ppm}\left(\mathrm{m}, 4 \mathrm{H}, \mathrm{C}_{5} \mathrm{H}_{3}\right) ;{ }^{13} \mathrm{C} \mathrm{NMR}$ $\left(300 \mathrm{MHz}, \mathrm{CDCl}_{3}\right): \delta=-1.39,-0.50\left(\mathrm{SiMe}_{2}\right), 135.6,136.5\left(\mathrm{C}_{5} \mathrm{H}_{3}\right)$, $141.4\left(\mathrm{C}_{\mathrm{ipso}}, \mathrm{C}_{5} \mathrm{H}_{3}\right), 183.7 \mathrm{ppm}\left(\mathrm{CO}_{3}\right)$; IR: $\tilde{v}=3218,2961(\mathrm{C}-\mathrm{H}$ $\left.\left(\mathrm{C}_{5} \mathrm{H}_{3}\right)\right), 1375\left(\mathrm{C}=\mathrm{O}\left(\mathrm{CO}_{3}{ }^{2-}\right)\right), 1262,1221\left(\mathrm{Si}-\mathrm{CH}_{3}\left(\mathrm{SiMe}_{2}\right)\right), 834,800$ (Ti-O-Ti), $676 \mathrm{~cm}^{-1}$ ( $\mathrm{Si}-\mathrm{Cp}$ ligand).

Received: February 25, 2005

Published online: August 4, 2005

Keywords: ab initio calculations - carbon dioxide fixation . silicon · titanium

[1] a) D. H. Gibson, Chem. Rev. 1996, 96, 2063; b) W. Leitner, Coord. Chem. Rev. 1996, 153, 257; c) X. Ling, J. R. Moss Coord. Chem. Rev. 1999, 181, 27.

[2] a) G. Parkin, Chem. Rev. 2004, 104, 699; b) S. Schenk, J. Kesselmeier, E. Anders, Chem. Eur. J. 2004, 10, 3091; c) H. Strasdeit, Angew. Chem. 2001, 113, 730; Angew. Chem. Int. Ed. 
2001, 40, 707; d) J. T. Cullen, T. W. Lane, F. M. M. Morel, R. M. Sherrell, Nature 1999, 402, 165.

[3] a) N. Kitajima, S. Hikichi, M. Tanaka, Y. Morooka, J. Am. Chem. Soc. 1993, 115, 5496; b) A. Escuer, R. Vicente, S. B. Kumar, X Solans, M. Font-Bardía, J. Chem. Soc. Dalton Trans. 1997, 403, c) R. A. Allred, L. H. McAlexander, A. M. Arif, L. M. Berreau Inorg. Chem. 2002, 41, 6790; d) C. Bergquist, T. Fillebeen, M. M. Morlok, G. Parkin, J. Am. Chem. Soc. 2003, 125, 6189; e) E. García-España, P. Gavina, J. Latorre, C. Soriano, B. A. Verdejo, J. Am. Chem. Soc. 2004, 126, 5082.

[4] J. Beckmann, D. Dakternieks, A. Duthie, N. A. Lewcenko, C. Mitchell, Angew. Chem. 2004, 116, 6851; Angew. Chem. Int. Ed. 2004, 43, 6683.

[5] a) T. C. W. Mak, P. J. Li, C. M. Zheng, K. Y. Huang, J. Chem. Soc. Chem. Commun. 1986, 1597; b) M. C. Suen, G. W. Tseng, J. D. Chen, T. C. Keng, J. C. Wang, Chem. Commun. 1999, 1185 c) F. A. Cotton, C. Lin, C. A. Murillo, J. Am. Chem. Soc. 2001, 123, 2670; d) G. Fachinetti, C. Floriani, A. Chiesivilla, C. Guastini, J. Am. Chem. Soc. 1979, 101, 1767; e) V. V. Burlakov, F. M. Dolgushin, A. I. Yanovsky, Y. T. Struchkov, V. B. Shur, U. Rosenthal, U. Thewalt, J. Organomet. Chem. 1996, 522, 241.

[6] M. Sudupe, J. Cano, P. Royo, E. Herdtweck, Eur. J. Inorg. Chem. 2004, 3074

[7] a) V. Ugrinova, G. A. Ellis, S. N. Brown, Chem. Commun. 2004, 468; b) R. Bortolin, V. Patel, I. Munday, N. J. Taylor, A. J. Carty, J. Chem. Soc. Chem. Commun. 1985, 456.

[8] G. Hidalgo, M. A. Pellinghelli, P. Royo, R. Serrano, A. Tiripicchio, J. Chem. Soc. Chem. Commun. 1990, 1118.

[9] S. Ciruelos, T. Cuenca, P. Gómez-Sal, A. Manzanero, P. Royo, Organometallics 1995, 14, 177.

[10] Crystal data for 3: $\left(\mathrm{C}_{11} \mathrm{H}_{16} \mathrm{Cl}_{5} \mathrm{O}_{3} \mathrm{Si}_{2} \mathrm{Ti}\right), M_{\mathrm{r}}=477.57$, monoclinic, space group $P 2_{1} / c, \quad a=10.5230(3), \quad b=9.5400(10), \quad c=$ 19.787(3) $\AA, \quad \beta=96.016(6)^{\circ}, \quad V=1975.5(4) \AA^{3}, \quad Z=4, \quad \rho_{\text {calcd }}=$ $1.606 \mathrm{~g} \mathrm{~cm}^{-3}, \mathrm{~F}(000)=964, \mathrm{Mo}_{\mathrm{K} \alpha}$ radiation $(\lambda=0.71073 \AA), \mu=$ $1.236 \mathrm{~mm}^{-1}$; crystal dimensions $0.51 \times 0.36 \times 0.16 \mathrm{~mm} . R_{1}\left(F^{2}>\right.$ $\left.2 \sigma\left(F^{2}\right)\right)=0.0311, \quad w R_{2}\left(F^{2}>2 \sigma\left(F^{2}\right)\right)=0.0703, \quad R_{1}\left(F^{2}\right)=0.0452$, $\left.\mathrm{w} R_{2}\left(F^{2}\right)=0.0741\right)$. Final-difference Fourier maps showed no

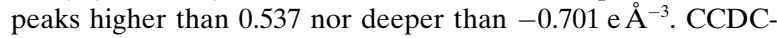
262845 contains the supplementary crystallographic data for this paper. These data can obtained free of charge from the Cambridge Crystallographic Data Center via www.ccdc.cam. ac.uk/data request/cif.

[11] a) A. Decker, D. Fenske, K. Maczek, Angew. Chem. 1996, 108 , 3025; Angew. Chem. Int. Ed. Engl. 1996, 35, 2863; b) A. Roth, C. Floriani, A. Chiesivilla, C. Guastini, J. Am. Chem. Soc. 1986, 108, 6823.

[12] Single point from the X-ray structure as well as geometrical optimization with the Hartree-Fock (HF) and B3Lyp methods with the 3-21G(d) basis set were performed by using the Gaussian 98 suite of programs (see ref. [23])

[13] All the theoretical calculations were made with: Gaussian 98, (Revision A.7): M. J. Frisch, et al. (see Supporting Information)

[14] Multiconfigurational CASSCF(2,2)/LANL2DZ calculations describe only qualitatively (not quantitatively) the energy of the singlet and triplet states, whereas geometrical optimization at this level gives a very accurate structure compared with the $\mathrm{X}$ ray data (see Supporting Information).

[15] Moller-Plesset up to second-order calculation (MP2) with a LANL2DZ basis set were used to determine the energetics by using the optimized CASSCF(2,2)/LANL2DZ geometry.

[16] The calculated difference of the density matrix elements between the $S_{0}$ and $T_{1}$ states reflects a high depopulation of the $\mathrm{Ti}-\mathrm{Ti}$ shared density in the excitation to $\mathrm{T}_{1}$ (approximately 0.8 e; see Supporting Information).

[17] Spin-orbit coupling calculated at $\operatorname{CASSCF}(2,2) / 3-21 \mathrm{G}(\mathrm{d})$ for the $\mathrm{S}_{0}$ equilibrium geometry is equal to $16.80 \mathrm{~cm}^{-1}$. 